\title{
Exploring Creative Thinking of Undergraduate Students through the Lens of Selected Demographic Variables
}

\author{
Muhammad Nadeem Anwar ${ }^{1}$, Asma Khizar², Musarat Azhar 3 \\ ${ }^{1}$ Assistant Professor, Department of Education, University of Sargodha, Sargodha \\ ${ }^{2}$ Lecture, Department of Education, University of Gujrat, Gujrat \\ ${ }^{3}$ Lecturer, Department of English, University of Sargodha, Sargodha
}

\section{A B S T R A C T}

Creativity is on top most agenda of the world today given its implication to literally every field of life. Demographic characteristics have been frequently and predictably related to creative thinking. The purpose of this study was to explore the perceptions of undergraduate university students about their creative thinking abilities and to assess the effect of some selected demographical variables on their perceived creative thinking abilities. A survey was administered to 200 undergraduate students who have been sampled purposively. The statistical analysis revealed that parental education contributes the highest, whereas the academic area of study has the lowest contribution to creative thinking. The gender and residential area also have a significant effect on perceived creative thinking abilities. Therefore it can be concluded that demographic variables of gender, parents' education, residential location and academic area of study are good predictors of creative thinking.

KEYWORDS: Demographic Variables, Creative thinking, Undergraduate Students

\section{INTRODUCTION}

Creativity is involved in almost every dimension of life ranging from wearing clothes to making breakfast and driving care to an office building. Since the time of Galton (1883), psychologists have shown an interest in creativity as an academic area of study. Research in the field of creativity, in fact, over the last 4 decades has generated more than 9,000 published works (Hook \& Tegano, 2002; Runco, Nemiro, \& Walberg, 
1998). This is because the construct creativity is interesting and applicable in most of the fields. With the inculcation of research and technology, individual needs and educational perspectives are changing. At the start of $19^{\text {th }}$ century word 'create' was not very common but now it's very important. Now in every field, creative thinking is being focused and professional are striving to develop it (Kutnick, Layne, Jules, \& Layne, 2006).

Torrance (1962) explained creativity as the process of creating ideas or forming and testing hypotheses and communicating the findings. Creativity is a highly ambiguous concept that tends to be given different meanings depending on the discipline or practice to which it is related (Runco, 2007). Galton (1883) explained the creativity in terms of universally adopted factors such as appropriateness and novelty (i.e. Originality and newness). Van Hook and Tegano (2002) further elaborated that creativity is accepting new ideas, encouraging and exploring the unknown. Creativity engages students in divergent thinking. Although it is a subjective form of thinking it combines creative and critical thinking to make student as an independent individual who plays an active role in society (Edwards, 2001).

Creative thinking is just connecting things in imaginations, it is the process of coming up with new ideas or new approaches. According to Plucker, Beghetto, and Dow (2004), creative thinking is an interplay of aptitude, process, and environment which results in producing and designing a novel but useful product.

Creative thinking is very diverse and it involves the creation of new things. It revolves around the originality, flexibility, fluency, associative thinking, imagery, metaphorical thinking, attribute listing and forced relationship. Sternberg (1999) explicated that creative thinking is an association of divergent and logical thinking rooted in intuition. Divergent thinking generates many ideas to solve the problem in any situation. Some of these seem to be useful for finding solutions. A process of logical thinking is used to examine an appropriate solution. A logical thinking involved a systematic and rational process to verify and make a valid conclusion. The focus of divergent thinking is on flexibility, fluency, and novelty in mathematical problem solving and problem posing (Haylock, 1997; Hook \& Tegano, 2002; Kutnick et al., 2006). 
Three stages of development of creative thinking in problem-solving were highlighted by Gotoh (2004). According to him, the first stage is "the empirical or informal activity", the second stage is "the algorithmic or formal activity", while the third stage is "the constructive or creative activity". It is worth noted that, at $1^{\text {st }}$ stage, problems are resolved with the help of

practical or technical application of procedures and rules. At $2^{\text {nd }}$ stage calculation, manipulation, operation, and problem solving techniques are used explicitly. Whereas, in the third stage, unusual problems are resolved through the non-algorithmic decision making i.e. finding and developing any rule.

A lot of researches have been done in which creative thinking has been addressed with reference to gender, intelligence, age, and academic achievement (Anwar, Aness, Khizar, Naseer, \& Muhammad, 2012; Johnson, 2008; Layne, Jules, Kutnick, \& Layne, 2008; Mizuno et al., 2008; Naderi, Abdullah, Aizan, Sharir, \& Kumar, 2009; Naderi, Abdullah, Aizan, Sharir, \& Kumar, 2010; Parker et al., 2004; Runco, 2007; Thompson \& Zamboanga, 2004).

Demographic variables have significant importance in researchers. Examples of demographic characteristics include age, race, gender, ethnicity, religion, income, education, homeownership, sexual orientation, marital status, family size, health and disability status, and psychiatric diagnosis. According to Beins and McCarthy (2017)

Information regarding age, ethnicity, socio-economic status, educational level, gender, and language spoken by the participant should be provided along with additional information. The absence of demographic information cause risk of "absolutism" and phenomenon under study is taken same for all regardless of gender, age, race, and SES. Demographic information paves the way towards "universalism" (Beins \& McCarthy, 2017).

Although demographic variables are important, a few types of research have been found regarding the level of academic achievements, age and gender in relation to creative thinking construct (Ai, 1999; Anwar et al., 2012; Kutnick et al., 2006; Layne et al., 2008; Mossing, 2013). No study has been found to focus the other significant demographic variables other than gender and age. Therefore, in order to move towards 
the "universalism", it is pertinent to undertake a study to analyse the creative thinking in relation to some selected demographic variables.

The objective of the study was to find out the effect of demographics (gender, parent education, the area of residence and selection of program) on creative thinking of undergraduate students.

\section{RESEARCH METHODOLOGY}

\section{Population and Sample:}

All the undergraduate students of BS programs of the University of Sargodha were the population of the study. Twenty five students were selected from each stratum with respect to the type of demographic variable i.e. Gender, parent education, the area of residence and area of study. Total sample size comprised of 400 undergraduate students.

\section{Research Instrument:}

A self-developed tool was used in this research after reviewing the related literature especially the tests developed so far on creativity (Johnson, 2008; Khatena \& Torrance, 1976; Sternberg, 1999; Torrance, 1962; Torrance, Ball, \& Safter, 1966). This instrument comprised 30-item, self-reported checklist designed to know the students' perception of their own behavior. This instrument was finalized after pilot testing and it demonstrated adequate reliability i.e. 0.81 .

The Student Demographic Information Sheet (TSDIS) was prepared to ask students about the information such as name, sex, age, parental education, area of residence and selected program of study. Data collected were analyzed, in addition to the descriptive statistics, the coefficient of correlation, t-test, one-way ANOVA, and regression analysis was computed. The Student Demographic Information Sheet (TSDIS) was prepared to ask students about the information such as name, gender, age, parental education, area of residence and selected program of study. Data were analyzed using the descriptive statistics, t-test, and regression analysis. 


\section{RESULTS}

\section{Table 1: Demographic Comparison of Creative Thinking}

\begin{tabular}{|c|c|c|c|c|c|c|c|}
\hline $\begin{array}{l}\text { Demographic } \\
\text { Variables }\end{array}$ & $\begin{array}{l}\text { Category } \\
\text { of variable }\end{array}$ & $\mathbf{N}$ & Mean & SD & $\begin{array}{c}\text { Mean } \\
\text { Difference }\end{array}$ & SEM & $t$ \\
\hline \multirow{2}{*}{ Gender } & Male & 50 & 3.91 & 1.09 & \multirow{2}{*}{0.31} & \multirow{2}{*}{0.15} & \multirow{2}{*}{$2.05^{*}$} \\
\hline & Female & 50 & 4.22 & 1.12 & & & \\
\hline \multirow{2}{*}{$\begin{array}{l}\text { Parental } \\
\text { Education }\end{array}$} & Literate & 50 & 4.60 & 1.76 & \multirow{2}{*}{1.39} & \multirow{2}{*}{0.51} & \multirow{2}{*}{$2.95^{*}$} \\
\hline & Not literate & 50 & 3.21 & 1.13 & & & \\
\hline \multirow{2}{*}{ Area of Residence } & Urban & 50 & 3.42 & 1.49 & \multirow{2}{*}{0.23} & \multirow{2}{*}{0.11} & \multirow{2}{*}{$2.91 *$} \\
\hline & Rural & 50 & 3.19 & 1.39 & & & \\
\hline \multirow{2}{*}{ Area of study } & $\begin{array}{l}\text { Management } \\
\text { Science }\end{array}$ & 50 & 1.90 & 1.19 & \multirow{2}{*}{0.13} & \multirow{2}{*}{0.05} & \multirow{2}{*}{0.75} \\
\hline & $\begin{array}{l}\text { Social } \\
\text { Sciences }\end{array}$ & 50 & 2.03 & 1.30 & & & \\
\hline
\end{tabular}

* Significant at 0.05 level of confidence

Table 1 shows the categorical description of each demographic variable. The results showed the significant difference between girls and boys in creative thinking $(t=$ $2.05, \mathrm{p}>0.05)$, parental education $(t=2.95, \mathrm{p}>0.05)$, urban and rural students $(t=2.91$, $\mathrm{p}>0.05)$ and academic area of study $(t=0.75, \mathrm{p}<0.05)$.

\begin{tabular}{|l|l|l|l|l|l|}
\hline \multicolumn{6}{|c|}{ Table 2: Regression Analysis of Demographic Variables and Creative Thinking } \\
\hline Source of Variation & df & Sum of Square & Mean Square & F-ratio & p-value \\
\hline Regression & 3 & 60324.026 & 6768.32 & 125.75 & 0.000 \\
Residual & 396 & 31698.408 & 51.53 & & \\
\hline
\end{tabular}

\begin{tabular}{|l|c|c|c|}
\hline Multiple R & R Square & Adjusted R Square & Standard error \\
\hline 0.706 & 0.561 & 0.635 & 7.23 \\
\hline
\end{tabular}

The result is showing in table 2 that all the four demographic variables jointly gave a coefficient of multiple regression $(R)=0.706$ and correlation square $\left(R^{2}\right)=0.561$ and an adjusted correlation square $\left(\operatorname{Adj} R^{2}\right)=0.635$, which indicates that the four demographic variables jointly contribute a total of $56.1 \%$ variance of the creative thinking. 


\begin{tabular}{|l|c|c|c|}
\hline \multicolumn{4}{|c|}{ Table 3: Effect of Demographic Variables and Creative Thinking } \\
\hline Predictor & $\boldsymbol{\beta}$ & $\boldsymbol{t}$-ratio & p-value \\
\hline Gender & 0.234 & 06.561 & $<0.05$ \\
Parental Education & 0.532 & 11.106 & $<0.05$ \\
Area of Residence & 0.247 & 06.592 & $<0.05$ \\
Area of study & 0.012 & 0.123 & $<0.05$ \\
\hline
\end{tabular}

The result shows in table 3 that parental education contributes the highest with $\beta$ $=0.532$ with $t=11.106$ at 0.05 level of confidence, whereas the area of study in undergraduate classes has the lowest contribution with a $\beta=0.012$. The magnitude of the gender and residential area are $\beta=0.234 ; \mathrm{t}=6.561 ; \mathrm{p}<0.05$ and $\beta=0.247 ; t=6.592$; $\mathrm{p}<0.05$ respectively. Therefore, it is concluded that the demographic variables significantly predicted the creative thinking.

\section{Discussion}

The aim of this research was to primarily determine the relationship of creative thinking through the lens of some selected demographic variables. The statistical analysis showed that parental education contributes the highest with the $\beta$ weight of 0.532 selection of a program of study has the lowest contribution with a $\beta$ weight of 0.012 , with $t=0.123$ at 0.05 level of significance. This clearly indicated that demographic variables (gender, parent education, the area of residence and selection of program) are good predictors of creative thinking among undergraduate university students.

Findings of the current study are aligned with previous researchers. (Batey, Furnham, \& Safiullina, 2010; Leu \& Chiu, 2015; Naderi et al., 2009) concluded that age and gender and creativity are the predictors of academic achievement. Ai (1999) explored the relationship among self-regulation and creativity of college students and compatibility of self-regulation, creativity, and achievement with demographic factors. Purpose of this research was to explore either demographic trait are reliable predictors of creativity and self-regulation. It was concluded that non-consistent variables such as educational level, gender, and age were being significant predictors of creativity. A study conducted by Batey et al. (2010) examined variance in creativity due to demographics, personality, and intelligence. Results showed that age, gender, general knowledge, fluid intelligence, and 
big 5 personality traits effected creativity. Creativity is a complex construct and it is addressed with the help of intelligence. The teacher should acknowledge creative aspects among students to polish their potentials at all levels. The results indicate that all the demographic variables predict significantly to the creative thinking among undergraduate university students. However, before generalizing the results of current study sample size, environmental factor and other related variables should be kept in mind.

\section{REFERENCES}

Ai, X. (1999). Creativity and academic achievement: An investigation of gender differences. Creativity Research Journal, 12(4), 329-337.

Anwar, M. N., Aness, M., Khizar, A., Naseer, M., \& Muhammad, G. (2012). Relationship of creative thinking with the academic achievements of secondary school students. International Interdisciplinary Journal of Education, 1(3), 44-47.

Batey, M., Furnham, A., \& Safiullina, X. (2010). Intelligence, general knowledge, and personality as predictors of creativity. Learning and individual differences, 20(5), 532-535.

Beins, B. C., \& McCarthy, M. A. (2017). Research methods and statistics: Cambridge University Press.

Edwards, S. M. (2001). The technology paradox: Efficiency versus creativity. Creativity Research Journal, 13(2), 221-228.

Galton, F. (1883). Inquiries into the human faculty \& its development: JM Dent and Company.

Gotoh, G. (2004). The quality of the reasoning in problem solving processes. Paper presented at the The 10th International Congress on Mathematical Education.

Haylock, D. (1997). Recognising mathematical creativity in schoolchildren. ZDM, 29(3), 68-74.

Hook, C. W., \& Tegano, D. W. (2002). The relationship between creativity and conformity among preschool children. The Journal of Creative Behavior, 36(1), 1-16.

Johnson, G. M. (2008). Online study tools: College student preference versus impact on achievement. Computers in Human Behavior, 24(3), 930-939.

Khatena, J., \& Torrance, E. P. (1976). Khatena-Torrance creative perception inventory: Stoelting Company.

Kutnick, P., Layne, A., Jules, V., \& Layne, B. C. (2006). Academic achievement, pupil participation, and integration of group work skills in secondary school classrooms in the Caribbean. School of Education, UWI, St. Augustine.

Layne, A., Jules, V., Kutnick, P., \& Layne, C. (2008). Academic achievement, pupil participation, and integration of group work skills in secondary school classrooms in Trinidad and Barbados. International Journal of Educational Development, 28(2), 176-194.

Leu, Y.-C., \& Chiu, M.-S. (2015). Creative behaviors in mathematics: Relationships with abilities, demographics, affects and gifted behaviors. Thinking Skills and Creativity, 16, 40-50.

Mizuno, K., Tanaka, M., Ishii, A., Tanabe, H. C., Onoe, H., Sadato, N., \& Watanabe, Y. (2008). The neural basis of academic achievement motivation. Neurolmage, 42(1), 369-378.

Mossing, S. (2013). The Importance of Creative Thinking and the Arts in Education.

Naderi, H., Abdullah, R., Aizan, H. T., Sharir, J., \& Kumar, V. (2009). Creativity, age, and gender as predictors of academic achievement among undergraduate students. Journal of American Science, 5(5), 101-112.

Naderi, H., Abdullah, R., Aizan, H. T., Sharir, J., \& Kumar, V. (2010). The relationship between creativity and academic achievement: $A$ study of gender differences. Journal of American Science, 6(1), 181-190.

Parker, J. D., Creque Sr, R. E., Barnhart, D. L., Harris, J. I., Majeski, S. A., Wood, L. M., . . Hogan, M. J. (2004). Academic achievement in high school: does emotional intelligence matter? Personality and Individual Differences, 37(7), 1321-1330. 
Plucker, J. A., Beghetto, R. A., \& Dow, G. T. (2004). Why isn't creativity more important to educational psychologists? Potentials, pitfalls, and future directions in creativity research. Educational Psychologist, 39(2), 83-96.

Runco, M. A. (2007). Achievement sometimes requires creativity. High Ability Studies, 18(1), 75-77.

Runco, M. A., Nemiro, J., \& Walberg, H. J. (1998). Personal explicit theories of creativity. The Journal of Creative Behavior, 32(1), 1-17.

Sternberg, R. J. (1999). Handbook of creativity: Cambridge University Press.

Thompson, R. A., \& Zamboanga, B. L. (2004). Academic aptitude and prior knowledge as predictors of student achievement in the introduction to psychology. Journal of educational psychology, 96(4), 778.

Torrance. (1962). Guiding creative talent.

Torrance, Ball, O. E., \& Safter, H. T. (1966). Torrance tests of creative thinking: Scholastic Testing Service.

Van Hook, C. W., \& Tegano, D. W. (2002). The Relationship between Creativity and Conformity among Preschool Children. Journal of Creative Behavior, 36(1), 1-16. 